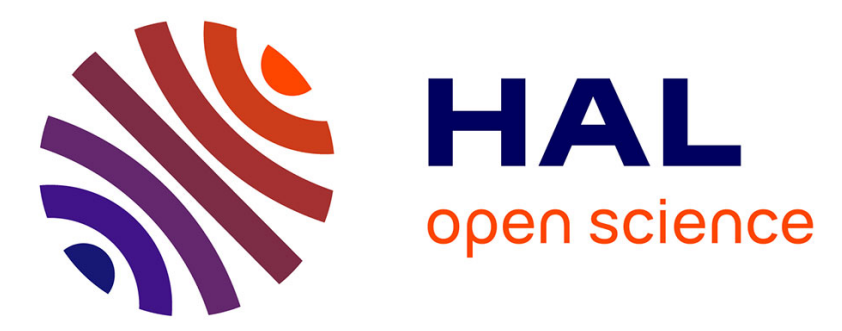

\title{
Fuel vertical structure affects fire sustainability and behaviour of prescribed burning in Spartium junceum shrublands
}

Daniele Castagneri, Assunta Esposito, Giovanni Bovio, Stefano Mazzoleni, Umberto Seneca, Ambra Catalanotti, Davide Ascoli

\section{- To cite this version:}

Daniele Castagneri, Assunta Esposito, Giovanni Bovio, Stefano Mazzoleni, Umberto Seneca, et al.. Fuel vertical structure affects fire sustainability and behaviour of prescribed burning in Spartium junceum shrublands. Annals of Forest Science, 2013, 70 (8), pp.863-871. 10.1007/s13595-013-0327-3 . hal-01201525

\section{HAL Id: hal-01201525 \\ https://hal.science/hal-01201525}

Submitted on 17 Sep 2015

HAL is a multi-disciplinary open access archive for the deposit and dissemination of scientific research documents, whether they are published or not. The documents may come from teaching and research institutions in France or abroad, or from public or private research centers.
L'archive ouverte pluridisciplinaire HAL, est destinée au dépôt et à la diffusion de documents scientifiques de niveau recherche, publiés ou non, émanant des établissements d'enseignement et de recherche français ou étrangers, des laboratoires publics ou privés. 


\title{
Fuel vertical structure affects fire sustainability and behaviour of prescribed burning in Spartium junceum shrublands
}

\author{
Daniele Castagneri - Assunta Esposito • Giovanni Bovio • \\ Stefano Mazzoleni - Umberto Seneca • \\ Ambra Elena Catalanotti • Davide Ascoli
}

Received: 27 January 2013 / Accepted: 26 August 2013 / Published online: 12 September 2013

(C) INRA and Springer-Verlag France 2013

\begin{abstract}
- Context Prescribed burning is increasingly recommended to control encroaching shrublands in the Mediterranean area.

- Aims The aims of this paper are to analyze the fuel structural characteristics of Spartium junceum and how they influence fire behaviour during prescribed burning.
\end{abstract}

\begin{abstract}
Handling Editor: Barry Alan Gardiner
Contribution of the co-authors D. Castagneri performed data analyses and wrote the first version of the manuscript. A. Esposito coordinated the design experiment, and participated to data collection. G. Bovio and S. Mazzoleni coordinated research projects. U. Seneca and A.E. Catalanotti carried out field sampling and laboratory analyses. D. Ascoli coordinated the design experiment, performed data collection and analyses, and reviewed results and discussion. All the co-authors contributed to the last version of the manuscript.
\end{abstract}

\author{
D. Castagneri $(\bowtie) \cdot G$. Bovio $\cdot$ D. Ascoli \\ Department of Agriculture, Forest and Food Sciences, University of \\ Turin, I-10095 Grugliasco, TO, Italy \\ e-mail: daniele.castagneri@unito.it \\ G. Bovio \\ e-mail: giovanni.bovio@unito.it \\ D. Ascoli \\ e-mail: d.ascoli@unito.it
}

A. Esposito $\cdot$ U. Seneca $\cdot$ A. E. Catalanotti

Department of Environmental, Biological and Pharmaceutical

Science and Technology, Second University of Naples,

I-81100 Caserta, CE, Italy

A. Esposito

e-mail: assunta.esposito@unina2.it

U. Seneca

e-mail: umbertoseneca@virgilio.it

A. E. Catalanotti

e-mail: ambraelena.catalanotti@unina2.it

\section{S. Mazzoleni}

Department of Agronomy, University of Naples Federico II, I-80055 Portici, NA, Italy

e-mail: stefano.mazzoleni@unina.it
- Methods Two winter-spring prescribed burns were conducted in 2009 and 2011. Fuel load and structure of $S$. junceum shrubs were assessed using the Cube Method, and shrub 3-D models were built using the FIRE PARADOX FUEL MANAGER software. Allometric equations to estimate $S$. junceum fuel load were developed. During burning, thermocouples measured temperature variations, which were then analyzed relative to fuel characteristics.

- Results Fuel load components and distribution were strictly related to shrub height; in tall shrubs, most of the fine fuel was more than $1.5 \mathrm{~m}$ aboveground. Due to fuel vertical discontinuity, not all shrubs were burned in the fires, but wind increased fire sustainment and fuel consumption. Maximum temperatures (over $800{ }^{\circ} \mathrm{C}$ ) and residence times were positively related to fuel load.

- Conclusion S. junceum tall shrublands represent high hazard formations due to their elevated fuel load, mostly in fine fuel fractions. Vertical discontinuity among fuel strata limits fire propagation in mild weather conditions. Winter-spring prescribed burning cannot eliminate $S$. junceum shrublands, but do create shrub cover discontinuity. As $S$. junceum has fire-adapted morphological traits, a single burn is insufficient to control it.

Keywords Cube method $\cdot$ Fuel structure $\cdot$ Prescribed burning $\cdot$ Residence time $\cdot$ Shrubland management $\cdot$ Spanish broom $\cdot$ Thermocouples

\section{Introduction}

Wildfires in the Mediterranean Europe cause large social, economic and environmental problems (Moreira et al. 2011). At the same time, fire is among the most important ecological factors shaping Mediterranean vegetation structure and functioning (Pausas et al. 2012). In the Mediterranean Basin, 
shrublands are among the most fire-prone vegetation types due to their high fine fuel particle content, short-lived fuel moisture content in summer and high volatile organic compound concentrations (Pellizzaro et al. 2007; Santana et al. 2011). In particular, landscape connectivity due to shrubland expansion from land use abandonment represents a serious fire hazard in the Mediterranean area and has implications for biodiversity conservation (Madrigal et al. 2012).

In Southern Europe, winter-spring prescribed burning in shrublands is increasingly recommended for fire hazard reduction, grazing management and nature conservation (Baeza and Vallejo 2008; Fernandes et al. 2013; Moreira et al. 2011). Information on canopy architecture, physical and chemical characteristics of fuel particles, and loading of live and dead fuels is essential to predict and understand prescribed fire behaviour in shrubland ecosystems (Krivtsov et al. 2009; Madrigal et al. 2012). Moreover, vegetation structure and horizontal and vertical fuel arrangement should be considered, as they strongly influence ignition patterns and spread (Fernandes and Cruz 2012).

In addition to fuel features, the assessment of fire front characteristics, such as the residence time of flame temperatures, is useful in understanding the effects of prescribed burns on soil physical and chemical characteristics, microbial communities, vegetation and wildlife (Fontúrbel et al. 2012; Iverson et al. 2004; Ventura et al. 1994; Wotton et al. 2012). Unexpectedly, temperature variations have been rarely measured within Mediterranean shrublands during prescribed burning under operational conditions, while most information derives from experimental fires under controlled conditions (De Luis et al. 2004; Molina and Llinares 2001; Santana et al. 2011; Silvani and Morandini 2009; Stoof et al. 2013).

A number of studies on fuel characteristics and fire behaviour in shrubland communities have been conducted, but due to high species diversity and structural complexity, a complete description of all the Mediterranean formation types is a far-off goal. Even shrublands dominated by Spanish broom (Spartium junceum L.), a leguminous shrub native to the Mediterranean area, have scarcely been studied. In Italy, this species is widely distributed, especially in coastal regions where it forms both mixed (Mediterranean maquis) and monospecific formations. Despite the fact that this is not an invading alien species in southern Europe, $S$. junceum encroaching produces management issues. In Southern France, winter-spring prescribed burning is increasingly applied to shrublands, including $S$. junceum formations, for fire hazard reduction, grazing management and habitat conservation. Moreover, while landscape managers in other Mediterranean countries are interested in this technique (Ascoli and Bovio 2013; Baeza and Vallejo 2008), little knowledge about $S$. junceum fuel and prescribed fire behaviour is available.

We analyzed two prescribed burns conduced in the winterspring period of 2009 and 2011 in the Cilento e Vallo di Diano
National Park, Southern Italy. The selected areas were abandoned pastures now dominated by $S$. junceum clusters as tall as $4 \mathrm{~m}$. Some newly developed methods to assess fuel load and distribution within the shrubs were employed. Temperature variations during the burns were monitored with thermocouples. Our research aimed at answering several specific questions: (1) What were the fuel characteristics of $S$. junceum? (2) What was the relationship between $S$. junceum size, fuel load and the vertical arrangement of the fuel? (3) Were temperature variation and fire behaviour related to fuel characteristics?

\section{Material and methods}

\subsection{Study area}

The study was conducted at Sella del Corticato, within the Cilento e Vallo di Diano National Park (hereafter Cilento Park), Southern Italy. Soils there are Eutri-Skeletic Cambisols (FAO classification). The bioclimatic belt is mesotemperate humid with a mean annual temperature of $14.7^{\circ} \mathrm{C}$ ranging between $6.3{ }^{\circ} \mathrm{C}$ in January to $23.6{ }^{\circ} \mathrm{C}$ in August (Sala Consilina meteorological station, $580 \mathrm{~m}$ a.s.1., $13 \mathrm{~km}$ from study site). Annual precipitation is $825 \mathrm{~mm}$ with a summer dry period of less than $100 \mathrm{~mm}$ (Gioi station, $684 \mathrm{~m}$ a.s.l., $22 \mathrm{~km}$ from study site). In Cilento Park, summer wildfires represent a serious concern, and shrublands are the most affected communities (Mazzoleni et al. 2001). Prescribed burning experiments program were carried out between 2009 and 2011 to open shrublands for grazing, prevent pastoral fire use in summer, and favor valuable grassland habitats (Ascoli et al. 2012).

The intervention site is a $15-20^{\circ}$ slope facing SE, at $830 \mathrm{~m}$ a.s.l. $\left(40^{\circ} 23^{\prime} \mathrm{N}, 15^{\circ} 26^{\prime} \mathrm{E}\right)$. The shrub layer is mainly composed of $S$. junceum, with minor extents of Rubus ulmifolius Schott, Prunus spinosa L., and Crataegus monogyna Jacq. Encroaching shrublands form clusters 3$4 \mathrm{~m}$ tall, where canopy cover reached $80-100 \%$. They represent a secondary re-colonization stage of abandoned pastures. Prior to 2009, the site had not been affected by fire for at least 20 years (Strumia 1995).

\subsection{Plant species}

S. junceum is a perennial, leguminous shrub native to the Mediterranean Basin, while in other regions it is considered an invasive species. Mature plants have one to several cylindrical stems up to $5 \mathrm{~m}$ tall, on which small $(2-2.5 \mathrm{~cm}$ long) leaves remain for a few months. Photosynthetic twigs, mostly $<1 \mathrm{~cm}$ in diameter, comprise the largest fraction of the plant crown (Zouhar 2005). S. junceum can form dense patches or grow as isolated individuals. It colonizes abandoned agricultural lands and rangelands and, as with other shrubs, it is 
expanding its reach in the Northern Mediterranean countries (Corona et al. 2012; Travlos et al. 2007). While it is considered a fire-prone species, empirical studies on flammability and post-fire regeneration dynamic are scant (Strumia 1995; Travlos et al. 2007; Zouhar 2005).

\subsection{Fuel characterization}

During April 2010, a field survey was conducted in the intervention site to assess $S$. junceum fuels. Three individuals from each of four height classes $(\leq 100,101-200,201-300$, $>300 \mathrm{~cm}$ ) were selected. Plant height, diameter at the root collar of each stem (shrubs were multi-stemmed) and four crown radii were measured. A marked rod was positioned close to each individual to scale photos of two orthogonal profiles. To characterize the fuels, we used the cube method (Cohen et al. 2002; Lecomte et al. 2008; Morsdorf and Allgöwer 2007), a recently developed partially destructive method. Following Cohen et al. (2002), we identified three cube types within each $S$. junceum individual: (1) top, representing the outermost canopy layer; (2) center, in the innermost part of the shrub canopy; (3) base, representing the base of the shrub (Morsdorf and Allgöwer 2007). Within each 25 -cm side cube, fuel particles with a diameter $\leq 25 \mathrm{~mm}$ were cut and stored.

In the laboratory, fuels were sorted into dead and live fractions and size classes $(0-2,2-6,6-25 \mathrm{~mm})$. A total of 216 samples ( 3 live +3 dead fuel size classes, 3 cubes, 12 shrubs) were dried at $95{ }^{\circ} \mathrm{C}$ for $24(0-6 \mathrm{~mm}$ particles $)$ or 48 $(>6 \mathrm{~mm}) \mathrm{h}$ to assess dry weight. Particle density was calculated as the ratio between sample dry weight and volume measured by water immersion. For each cube, fuel size class, and dead/live fraction we computed volume, fuel dry weight, and bulk density (ratio between fuel dry mass and cube volume in kilogram per cubic meter). Also calculated was the packing ratio, a dimensionless ratio between bulk density and particle density, which is an index of fuel porosity related to flammability (Krivtsov et al. 2009). We then assessed the parameters of the mean top, center and base cube, and employed the Kruskal-Wallis and median tests to evaluate differences between cube type characteristics.

In a successive step, we computed the fuel characteristics of each $S$. junceum individual by using two tools developed by the Fire Paradox Project (Dupuy and Alexandrian 2010). These included the on-line object-oriented Fire Paradox database (Krivtsov et al. 2009) that can be accessed after an authorization process managed by INRA of France, and the FIRE PARADOX FUEL MANAGER (FPFM) software module (Rigolot et al. 2010) of the CAPSIS platform (DufourKowalski et al. 2012) that interacts with the Fire Paradox database (www.fireparadox.org) and is devoted to fuel modeling, fuel build-up, and fire effect assessment. Fuel characteristics of each cube type of $S$. junceum were first up-loaded into the Fire Paradox database. Based on field measurements and scaled pictures taken in the field, we reconstructed two orthogonal 2-D shapes of cubes for each $S$. junceum individual by using the Fuel Editor tool of the FPFM (Lecomte et al. 2008). Thereafter, we developed $S$. junceum objects in 3-D, and estimated the fuel load (in gram per square meter) for $<25 \mathrm{~mm}$ particles along a vertical profile. To assess the total fuel load, we added the dry weight of stems (diameter $>25 \mathrm{~mm}$ ), calculated from the trunk volume (estimated from field measurements) and wood density (samples volume calculated by water immersion, dry weight measured after drying at $95^{\circ} \mathrm{C}$ ). Measured values were used to elaborate allometric equations that estimate fuel load of different particles from shrub height. Finally, we computed fuel vertical distribution within $S$. junceum shrublands. Field sampling was carried out in the vicinity of the study area in ten 100$\mathrm{m}^{2}$ plots of different height and coverage. The height of each shrub in the plots was measured. Using the allometric equations, we assessed individual fuel load along the vertical profile, and then we computed fuel distribution at the plot level.

\subsection{Prescribed burning}

The first burn was performed on 13 May 2009, and it covered an area of about 2 ha. The second fire was done on 10 February 2011 on an area of $8 \mathrm{ha}, 3 \mathrm{~km}$ from the location of the first one. In both burns, fire was ignited using drip torches by placing several spot ignitions at the border of each $S$. junceum cluster on the upwind and downslope side, so a headfire could spread through the cluster. The goal was to create a self-sustaining fire front with moderate intensity, capable of burning most of $S$. junceum of each cluster and spread through less accessible clusters. The burn in May 2009 started at approximately 1:00 p.m. and ended at 3:30 p.m. Seven days had occurred since the last rain and the mean air temperature was $24{ }^{\circ} \mathrm{C}$ with a relative air humidity of $40 \%$ and wind speed between 2 and $7 \mathrm{~km} \mathrm{~h}^{-1}$. The mean Fire Weather Index (FWI) of the previous 10 days was 2.25 (very low), and reached 7.34 (low) the day of the burn (data source: European Forest Fire Information System-EFFIS). The second burn lasted from 1:00 to 4:30 p.m. and 8 days had passed since the last rain. The mean air temperature was $15^{\circ} \mathrm{C}$ and wind speed was similar to that of the 2009 fire while air humidity averaged $67 \%$. The mean FWI of the previous 10 days was 0.47 (very low), and reached 2.01 (very low) the day of the burn. The moisture content of dead fine fuels was estimated from days since the last rain and air relative humidity by using a specific equation for Mediterranean shrub fuels (Fernandes et al. 2002). Mean dead fine fuel moisture on a dry weight basis was 14 and $19 \%$, during the first and second burn, respectively. As Mediterranean shrub live fuel 
moisture has little dependence on the weather (it varies only slightly between winter and spring, Pellizzaro et al. 2007), and has a negligible effect on fuel flammability (Fernandes and Cruz 2012; Madrigal et al. 2012), it was not considered in the present analysis.

\subsection{Fire behaviour characterization}

During prescribed burns fire behaviour was assessed for tall and large shrub clusters (radius 10-20 m), the fuel load of which was assessed from mean shrub height using the allometric equations realized in the current study.

A marked rod was placed in front of each shrub cluster to estimate flame length range in the field and to interpret photos and videos. Fireline intensity was calculated averaging predictions of relationships between flame length and intensity for Mediterranean shrublands, e.g., Eqs. 12, 15, 16, 17 in Alexander and Cruz (2012). Percentage fuel consumption was visually estimated using a shrub fuel consumption scale (Fernandes et al. 2002). Temperature during the fire propagation was measured using K-thermocouples $(0.4 \mathrm{~mm})$ which register temperature variation every $1 \mathrm{~s}$. Thermocouple probes (TCPs) were placed in the middle of shrub clusters (10 TCPs in 2009,15 TCPs in 2011) at 0.1 to $0.5 \mathrm{~m}$ above the ground (i.e. the base cube fuel layer). The sensors were connected to a HOBO data logger (Onset Computer Corporation, Bourne, MA) via cables protected by aluminum sheets. Data loggers were placed in PVC boxes and buried in the soil. Special care was taken to minimize fuel alteration in the TCP installations. A portable meteorological station measured wind speed at a height of $2 \mathrm{~m}$, as well as air temperature and air relative humidity on the upwind side of shrub clusters.

Temperature profiles allowed several assessments: (1) the maximum temperature reached in the flame; (2) the duration of temperature above different thresholds commonly used in literature $\left(60,100,200,300\right.$, and $\left.400{ }^{\circ} \mathrm{C}\right)$; (3) the time-temperature integration (sum of temperatures registered every second above the same thresholds) (Bova and Dickinson 2005; Iverson et al. 2004); (4) the duration of pre-heating phase defined as the period between ambient temperature and $60{ }^{\circ} \mathrm{C}$ (the lethal temperature for vegetative tissues) (Ventura et al. 1994); (5) the duration of temperature rise before ignition, which is the elapsed time between 60 and $300{ }^{\circ} \mathrm{C}$ considered as the lower limit of flaming combustion (Wotton et al. 2012).

A redundancy analysis (RDA) was used to investigate the relationships among fuel and weather characteristics (explicative variables) and temperature parameters (response variables) (Davies et al. 2009). RDA was performed on Canoco 4.0 software (Microcomputer Power, Ithaca, NY) and the statistical significance of the relationship between variables was tested by a Monte Carlo procedure with 10,000 permutations.

\section{Results}

\subsection{Cube fuel characteristics}

Twig particle $(0-6 \mathrm{~mm})$ density was $0.31( \pm 0.02) \mathrm{g} \mathrm{cm}^{-3}$, while wood density (particles $>6 \mathrm{~mm}$ ) was $0.58( \pm 0.03)$ $\mathrm{g} \mathrm{cm}^{-3}$ Among the three types of cubes, and in all size classes, the living portion was larger than the dead portion (except for 2-6 mm particles in the base cube, Table 1). The amount of living and dead 0-2 $\mathrm{mm}$ particles, and of living 2-6 mm particles were similar between the cubes while the dead particles of 2-6 $\mathrm{mm}$ size differed slightly (KruskalWallis test, $p=0.030$; median test, $p=0.097$ ). All the other particle classes, cube weight, bulk density, and packing ratio differed at $p<0.005$.

The mean base cube was composed primarily of twigs $6-$ $25 \mathrm{~mm}$ in size with high values for load, bulk density, and packing ratio. The quantity of dead large particles was the highest among the various cubes; dead particles represented $36 \%$ of the total load, but $64 \%$ of load $<6 \mathrm{~mm}$. The center cube was composed primarily of living 2-6-mm and 6-25mm particles; dead particles were $26 \%$ of the total load. Bulk density and packing ratio were intermediate relative to the other cubes. Finally, the top cube was considerably lighter than the others; it had the lower bulk density and packing ratio. In addition, very few particles $>6 \mathrm{~mm}$ were present, and dead load was $24 \%$ of the total.

\subsection{Shrub individual fuel load and distribution}

Selected S. junceum individuals were $213 \mathrm{~cm}$ tall on average (Table 2). Each shrub had several stems, with thin bark of only

Table 1 Mean characteristics of cube types. Different letters indicate significantly different means between cube types (Kruskal-Wallis test, pair-wise comparison)

\begin{tabular}{|c|c|c|c|c|c|c|c|c|c|}
\hline Cube type & $\begin{array}{l}\text { Live load } \\
0-2 \mathrm{~mm} \\
\text { (g) }\end{array}$ & $\begin{array}{l}\text { Live load } \\
2-6 \mathrm{~mm} \\
(\mathrm{~g})\end{array}$ & $\begin{array}{l}\text { Live load } \\
6-25 \mathrm{~mm} \\
(\mathrm{~g})\end{array}$ & $\begin{array}{l}\text { Dead load } \\
0-2 \mathrm{~mm} \\
(\mathrm{~g})\end{array}$ & $\begin{array}{l}\text { Dead load } \\
2-6 \mathrm{~mm} \\
(\mathrm{~g})\end{array}$ & $\begin{array}{l}\text { Dead load } \\
6-25 \mathrm{~mm} \\
(\mathrm{~g})\end{array}$ & $\begin{array}{l}\text { Total load } \\
\text { (g) }\end{array}$ & $\begin{array}{l}\text { Bulk density } \\
\left(\mathrm{g} / \mathrm{dm}^{3}\right)\end{array}$ & Packing ratio \\
\hline Base & $3.0 \mathrm{a}$ & $10.4 \mathrm{a}$ & $78.5 \mathrm{a}$ & $1.6 \mathrm{a}$ & $22.2 \mathrm{a}$ & $28.2 \mathrm{a}$ & $143.9 \mathrm{a}$ & $9.21 \mathrm{a}$ & $0.019 \mathrm{a}$ \\
\hline Center & $3.2 \mathrm{a}$ & $28.4 \mathrm{a}$ & $29.4 \mathrm{a}$ & $2.4 \mathrm{a}$ & $14.8 \mathrm{ab}$ & $4.4 \mathrm{~b}$ & $82.6 \mathrm{ab}$ & $5.29 \mathrm{ab}$ & $0.014 \mathrm{ab}$ \\
\hline Top & $3.2 \mathrm{a}$ & $22.9 \mathrm{a}$ & $3.9 \mathrm{~b}$ & $1.1 \mathrm{a}$ & $8.2 \mathrm{~b}$ & $0.1 \mathrm{~b}$ & $39.4 \mathrm{~b}$ & $2.52 \mathrm{~b}$ & $0.008 \mathrm{~b}$ \\
\hline
\end{tabular}


$0.5 \mathrm{~mm}$ in small individuals and $1-1.5 \mathrm{~mm}$ in the largest ones. Using FPFM software, we arranged cubes within $S$. junceum objects. The number of base cubes ranged between 1 and 17, center cubes were 8 to 213 , and top cubes were 24 to 203 . The mean total fuel load was $4,558 \mathrm{~g} \mathrm{~m}^{-2}$. The fuel load of each component correlated highly $(p<0.001)$ to shrub height, allowing creation of allometric equations (linear models) to estimate fuel load from shrub height (Table 2). Mean load of twigs $0-2 \mathrm{~mm}$ represented $8.4 \%$ of total fuel load in the smaller class (shrubs $\leq 100 \mathrm{~cm}$ height) and $5.6 \%$ of fuel in the higher class (shrubs $>300 \mathrm{~cm}$ ). The $2-6 \mathrm{~mm}$ fraction was always the largest component. Stems (particles $>25 \mathrm{~mm}$ ) considerably enhanced the total load of the tallest individuals.

Dead particles represented almost one third of fine fuel ( $\leq 6 \mathrm{~mm}$ : the most important to fire ignition and propagation). The lower strata had more dead than live fuel as opposed to a scarce representation of dead particles in the higher strata (Fig. 1). Vertical distribution varied considerably relative to shrub height. In the shortest individuals, there was a large fine fuel load between 26 and $100 \mathrm{~cm}$ aboveground while in the higher class (101-200 cm), most of the fine fuel was between 26 and $175 \mathrm{~cm}$. For shrubs $201-300 \mathrm{~cm}$ tall, the lower $75 \mathrm{~cm}$ had few small particles. Finally, only $3-4 \%$ of fine fuels were located in the lower meter of individuals $>300 \mathrm{~cm}$; the largest part was at $151-250 \mathrm{~cm}$.

\subsection{Shrubland stand fuel load and distribution}

In the sampled plots, mean density equaled 3,230 $( \pm 572)$ shrubs ha ${ }^{-1}$ with a mean cover of $74( \pm 14) \%$. Mean height was $190( \pm 18) \mathrm{cm}$, but different height classes co-occurred in each plot, with individuals between $107( \pm 22)$ and $306( \pm 53)$ $\mathrm{cm}$. Using allometric equations, we estimated mean $S$. junceum fuel load to be $3.3( \pm 0.8) \mathrm{kg} \mathrm{m}^{-2}$, but it varied considerably in relation to percentage cover and height. In four plots with cover $<70 \%$ and mean height $<200 \mathrm{~cm}$, the load averaged $2.6 \mathrm{~kg} \mathrm{~m}^{-2}$ as opposed to four other plots with cover $>80 \%$ and height $>200 \mathrm{~cm}$ that averaged $4.1 \mathrm{~kg} \mathrm{~m}^{-2}$. In the last two plots with intermediate cover and mean height it averaged $3.1 \mathrm{~kg} \mathrm{~m}^{-2}$. Within a plot stand we found most fine fuel (particles $\leq 6 \mathrm{~mm}$ ) located within the 101-150 cm (32\% on average) and $151-200 \mathrm{~cm}(28 \%)$ ranges aboveground. The amount of fuel at $51-100 \mathrm{~cm}$ varied in the range of 17 to $32 \%$. Fuel was quite limited in the lower $50 \mathrm{~cm}$, averaging just $8 \%$, and at more than $200 \mathrm{~cm}$, averaging $10 \%$.

\subsection{Temperature variations}

In both fires flame heights ranged between 1 and $4 \mathrm{~m}$ with an estimated fireline intensity of between 420 and $7,200 \mathrm{~kW} \mathrm{~m}^{-1}$. Fire behaviour was irregular and some clusters failed to burn. In these cases, the TCPs (two in 2009, four in 2011) that were not 

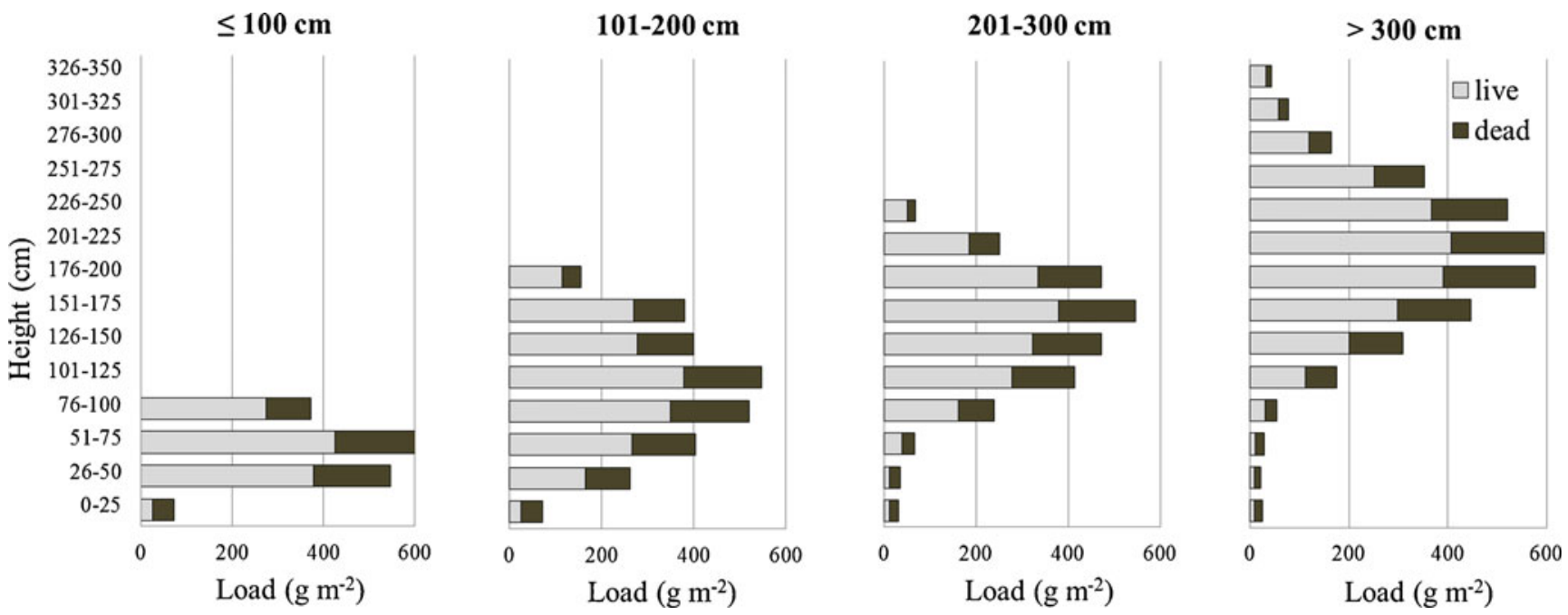

Fig. 1 Vertical distribution of live (grey) and dead (black) particles $\leq 6 \mathrm{~mm}$ for four height classes

directly affected by flames registered only moderate increases of temperature and were not considered in the analyses. Among the burnt clusters, three had an estimated fuel consumption of

Table 3 Parameters of fuel (explicative variables) and temperature profiles (response variables) employed in the RDA analysis

\begin{tabular}{lllll}
\hline Explicative variables & Short name & Median & Min & Max \\
\hline Fuel load $\left(\mathrm{g} \mathrm{m}^{-2}\right)$ & Fuel load & 6,961 & 5,151 & 7,260 \\
Fuel consumption (\%) & Burnt fuel & 90 & 40 & 95 \\
Dead fine fuel moisture (\%) & Fuel moisture & 18 & 13 & 20 \\
Wind speed $\left(\mathrm{m} \mathrm{s}^{-1}\right)$ & Wind speed & 4 & 3 & 5 \\
Response variables & & & & \\
Max temperature $\left({ }^{\circ} \mathrm{C}\right)$ & T_max & 666 & 335 & 956 \\
Time $20-60^{\circ}(\mathrm{s})$ & t_20-60 & 32 & 9 & 277 \\
Time $60-300^{\circ}(\mathrm{s})$ & t_60-300 & 24 & 1 & 195 \\
Time $>60^{\circ}(\mathrm{s})$ & t.60 & 389 & 52 & 1,570 \\
Time $>100^{\circ}(\mathrm{s})$ & t.100 & 275 & 19 & 1,465 \\
Time $>200^{\circ}(\mathrm{s})$ & t.200 & 151 & 12 & 892 \\
Time $>300^{\circ}(\mathrm{s})$ & t.300 & 87 & 2 & 527 \\
Time $>400^{\circ}(\mathrm{s})$ & t.400 & 48 & 0 & 388 \\
$\sum$ temperature $>60^{\circ}\left({ }^{\circ} \mathrm{C}-\mathrm{s}\right)$ & T.60 & 82,125 & 7,269 & 389,499 \\
$\sum$ temperature $>100^{\circ}\left({ }^{\circ} \mathrm{C}-\mathrm{s}\right)$ & T.100 & 76,835 & 5,003 & 385,917 \\
$\sum$ temperature $>200^{\circ}\left({ }^{\circ} \mathrm{C}-\mathrm{s}\right)$ & T.200 & 52,203 & 3,062 & 300,368 \\
$\sum$ temperature $>300^{\circ}\left({ }^{\circ} \mathrm{C}-\mathrm{s}\right)$ & T.300 & 36,148 & 645 & 228,754 \\
$\sum$ temperature $>400^{\circ}\left({ }^{\circ} \mathrm{C}-\mathrm{s}\right)$ & T.400 & 25,108 & 0 & 201,193 \\
\hline
\end{tabular}

Fuel load is the total fuel load of the shrub obtained from allometric equation. Fuel consumption is the percentage of burnt fuel $\leq 25 \mathrm{~mm}$. Dead fuel moisture is the moisture percentage of dead fine fuel. Wind speed is wind speed measured at $2 \mathrm{~m}$ above ground. Max temperature is the maximum temperature reached by the flame. Time $20-60^{\circ}$ is the duration of temperature rise between ambient temperature and $60^{\circ} \mathrm{C}$. Time 60 $300^{\circ}$ is the period between $60^{\circ} \mathrm{C}$ and $300^{\circ} \mathrm{C}$. Time $>60^{\circ},>100^{\circ},>200^{\circ}$, $>300^{\circ}$, and $>400^{\circ}$ are the duration of temperature above these thresholds. $\sum$ temperature $>60^{\circ},>100^{\circ},>200^{\circ},>300^{\circ}$, and $>400^{\circ}$ are sum of temperatures registered every second above these thresholds
40-60\% while the others were consumed at 80-95\% (Table 3). The high variability among the fire parameters was probably due both to the irregular fire front and to the intrinsic variability of flames in the field. Moreover, thermocouples compute point measurements and not the mean heat transfer in the fuel. This increased the variability of the retrieved information (Ventura et al. 1994; Wotton et al. 2012). The median maximum temperature was $666{ }^{\circ} \mathrm{C}$; in five cases it exceeded $800{ }^{\circ} \mathrm{C}$. The elapsed time between ambient temperature and $60{ }^{\circ} \mathrm{C}$ (preheating phase) was $32 \mathrm{~s}$, but in two cases it took more than $100 \mathrm{~s}$. The median residence time with temperature $>60^{\circ} \mathrm{C}$ was more than 6 min while residence time $>300^{\circ} \mathrm{C}$ was $87 \mathrm{~s}$. All but

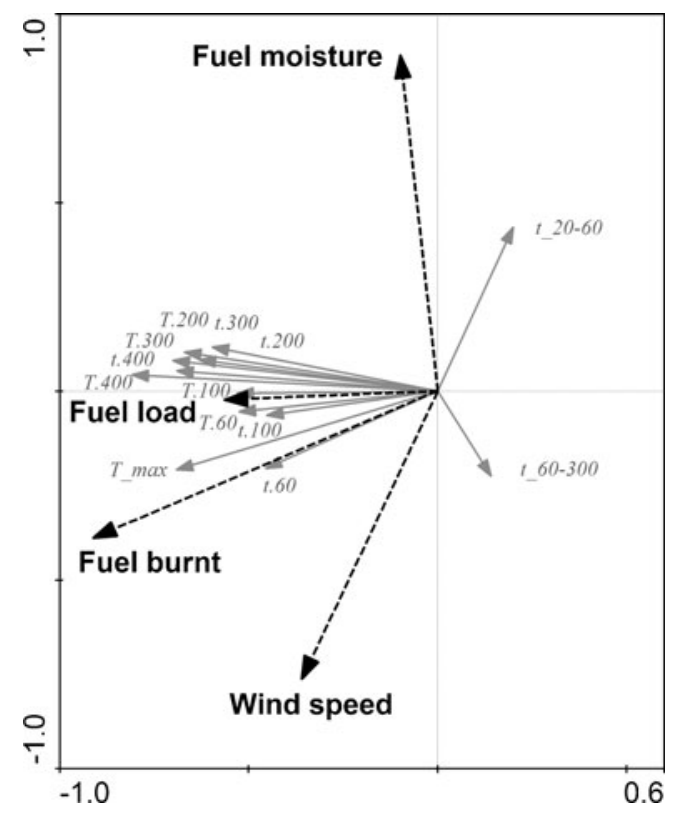

Fig. 2 Redundancy analysis ordination bi-plot. Dotted arrows (bold) represent the scores of fuel and weather variables (explanatory variables). Full-line arrows (italics) represent the scores of fire parameters (response variables). Details on variable names are reported in Table 3 
one temperature profile exceeded $400{ }^{\circ} \mathrm{C}$, and in eight cases this temperature lasted for more than $1 \mathrm{~min}$. As with residence times, integrated temperatures were highly variable.

The relationships between shrub characteristics and temperature profile descriptors were statistically significant $(p<0.05)$ in the RDA model (Fig. 2). The first axis explained $38.0 \%$ of the variance while the other axes had a lower influence (the second axis explained $2.5 \%$ of variance). Residence times and time-temperature integrations were positively related to one other. Maximum temperature was positively related to both parameters, especially with the duration of temperature $>60$ and $>100{ }^{\circ} \mathrm{C}$. On the contrary, the elapsed time between ambient temperature and $60{ }^{\circ} \mathrm{C}$ was slightly negatively related to fuel parameters and mostly to wind speed. Other weather variables were not included in the model as they were scarcely related to fire parameters. High load clusters generally burned to high percentages, and held high temperatures $\left(>200{ }^{\circ} \mathrm{C}\right)$ for longer times than did those of smaller load. The clusters that burned at higher percentages had a rapid pre-heating phase. The strong correlation with the duration of temperatures $>60{ }^{\circ} \mathrm{C}$ indicated that fuel consumption occurred even at low temperatures. Dead fine fuel moisture was related to the second axis and explained a low percentage of the variance. Indeed, it was negligibly related to temperature residences and fuel characteristics.

\section{Discussion}

This study improves the knowledge of fuel characteristics of $S$. junceum, a diffuse shrub species of Mediterranean vegetation scarcely studied in relation to fire behaviour. With a mean load of $4.5 \mathrm{~kg} \mathrm{~m}^{-2}$ at the individual level, and of 2.6 to $4.1 \mathrm{~kg} \mathrm{~m}^{-2}$ in formations with ground cover of $60-90 \%$, S. junceum has a rather high fuel load relative to other Mediterranean shrubs. Among leguminous shrubs, loads of $3.4 \mathrm{~kg} \mathrm{~m}^{-2}$ for Ulex parviflorus (Santana et al. 2011), $3.4 \mathrm{~kg} \mathrm{~m}^{-2}$ for Ulex europaeus (Puentes and Basanta 2002), and 2.0-3.7 kg m${ }^{-2}$ for U. parviflorus (De Luis et al. 2004) have been reported. For other shrub groups, $2.9 \mathrm{~kg} \mathrm{~m}^{-2}$ for Rosmarinus albidus, $2.1 \mathrm{~kg} \mathrm{~m}^{-2}$ for Cistus officinalis (Santana et al. 2011), 1.8 for Cistus salviifolius, and $3.0 \mathrm{~kg} \mathrm{~m}^{-2}$ for Cistus ladanifer (Simões et al. 2012) have been measured. However, all these shrubs were 1-2 m tall, while the $S$. junceum individuals we measured were more than $2 \mathrm{~m}$ on average. When fuel assessment is performed, shrub characteristics (e.g. height, diameter, age) should always be taken into account due to large differences in fuel vertical distribution and load between different size or age classes (Madrigal et al. 2012; Papiò and Trabaud 1991; Puentes and Basanta 2002).

In addition to the elevated load, $S$. junceum represented a high hazard fuel because most particles had diameters between 0 and $6 \mathrm{~mm}$, which is highly flammable. Similar to other Mediterranean shrubs, a large proportion of dead fuel was located at the base of individuals, a trait that favors fire ignition, while the lower bulk density we observed in the shrub canopy should favor crown fire spread (Fernandes and Cruz 2012). However, the morphological characteristics of vertical fuel discontinuity exhibited in tall S. junceum shrubs have rarely been observed in other shrub species (Papiò and Trabaud 1991). We believe this pattern affected fire behaviour in the intervention sites, where burnt clusters were $2.5-3.5 \mathrm{~m}$ tall with most of the fine fuel at $1.5-2.5 \mathrm{~m}$ aboveground. When fuel is arranged in this way, then after ignition surface fires require more favorable fire weather conditions (low air moisture with constant and intense winds) to spread throughout the crown layer. Prescribed burnings in 2009 and 2011 occurred in mild fire weather conditions, and dead fuel moisture levels, particularly in 2011. These conditions were close to marginal conditions for sustained crown fire spread (Anderson and Anderson 2010). Some S. junceum clusters were burned only marginally, and successive human-induced ignitions were required. In general, clusters with higher fuel loads were affected by higher temperatures and longer residences. The pre-heating phase (time between ambient temperature and $60^{\circ} \mathrm{C}$ ) and successive phase of temperature increase before flaming (time from 60 to $300{ }^{\circ} \mathrm{C}$ ) were negatively related to the other fire parameters. This phenomenon indicated that, compared to a slow fire, a faster fire front that is sustained by increased wind speed burns fuel at higher temperatures and with longer residences and causes more complete fuel consumption (Morandini et al. 2006).

Maximum temperatures as high as $956{ }^{\circ} \mathrm{C}$ and temperatures above $60^{\circ} \mathrm{C}$ (death of vegetative tissues) for durations of more than 6 min killed most of the aerial part of the shrubs in our study plots. Other Mediterranean shrubland studies of experimental fires registered maximum temperatures of 400 $600{ }^{\circ} \mathrm{C}$ and residence times above $100{ }^{\circ} \mathrm{C}$ for $10-30 \mathrm{~min}$ (De Luis et al. 2004; Molina and Llinares 2001). Much longer residences and lower temperatures might relate to different fuel and environmental conditions. However, other factors cannot be ruled out: less sensitive probe types (e.g. $1 \mathrm{~mm}$ TCPs) positioned at the soil surface generally register lower temperatures and longer residence times. In an experiment in Mediterranean maquis, Santoni et al. (2006) placed $0.25 \mathrm{~mm}$ thermocouples at $0.6 \mathrm{~m}$ above the ground. A maximum temperature of $1,060{ }^{\circ} \mathrm{C}$ and a residence time above $150{ }^{\circ} \mathrm{C}$ for $5 \mathrm{~min}$ were more similar to the temperatures registered in our study. Silvani and Morandini (2009) placed similar sensors at the top of $0.8-\mathrm{m}$ tall Mediterranean brooms and measured a maximum temperature of $790{ }^{\circ} \mathrm{C}$ and residence time above $300{ }^{\circ} \mathrm{C}$ for $40 \mathrm{~s}$. Morandini et al. (2006) measured a maximum temperature over $800{ }^{\circ} \mathrm{C}$ at $0.6 \mathrm{~m}$ above the ground in Mediterranean shrub vegetation, and residence time above $500{ }^{\circ} \mathrm{C}$ for $50-200 \mathrm{~s}$ using $0.50 \mathrm{~mm}$ K-type thermocouples. 


\section{Conclusions and management implications}

Shrublands expansion is a concern for both conservation of habitats and fire risk in the Mediterranean area. Our study showed that due to elevated fuel loads structural characteristics and spatial arrangement, tall $S$. junceum shrublands should certainly be considered highly hazardous formations. Allometric models developed herein, estimating fuel parameters from shrub height, could be useful for $S$. junceum shrublands fuel characterization when cover and height are derived from LiDAR images, increasingly used in fire hazard assessment.

Temperature and residence time were related to shrub height and indicated that fire in taller shrubs can be more severe than in shorter ones. Prescribed burning has been adopted to manage several shrub communities (Baeza and Vallejo 2008), and could be used to limit $S$. junceum encroachment. The interventions in this study occurred under mild fire weather conditions during the winter-spring; only trivial fire behaviour differences were observed between February and May. The fire front did not ignite all shrubs, which was probably due to fuel vertical discontinuity and marginal moisture conditions. Consequently, if the primary objective of prescribed burning is fire hazard reduction then more favorable fire weather would optimize shrub burning over contiguous, large areas, such as is needed for strategic fuel breaks (Fernandes et al. 2013). However, the burning created shrub cover discontinuity, resulting in diversification of the habitat structure and patchiness, which could be valuable for grazing management and conservation purposes (Pons et al. 2003).

Nevertheless, we believe that $S$. junceum encroaching cannot be repressed by a single burn. Shrubs of Mediterranean climate regions have been selected by a fire-prone environment (Baeza and Vallejo 2008): most of the crown is composed of flammable thin twigs, and dead fuel accumulates at the base. This allows fire propagation, which results in increased mortality of neighbouring species while creating, as a consequence, recruitment opportunities ("kill thy neighbour" hypothesis, see Pausas et al. 2012). Furthermore, S. junceum has a good re-sprouting capability following fire (Zouhar 2005) and seed germination is favored by temperatures near $100{ }^{\circ} \mathrm{C}$ (Hanley 2009; Travlos et al. 2007). We believe that $S$. junceum could re-colonize burnt stands, therefore ecological monitoring and successive interventions, such as maintenance prescribed burning and prolonged grazing-browsing, might be an important step in the years following the first burn aimed at controlling $S$. junceum recurrence.

Acknowledgments We thank the enterprise Gestão Integrada de Fogos Florestais S.A. (GIFF, S.A.; http://www.giff.pt/website/) for field burning operations, E. Rigolot for suggestions in using Fire Paradox and FPFM software, F. Negro and F. Ruffinatto for laboratory analyses, J. Leonard for revising our English and helpful comments, the editor and two anonymous reviewers for improving this manuscript. FWI data were provided by the EFFIS (http://effis.jrc.ec.europa.eu) of the European Commission Joint Research Centre.

Funding The work was part of the project PRIN 2009 "in_FLAMING: Developing innovative models and techniques for integrated fuel management for fire prevention in Mediterranean and temperate forests" (national coordinator: P. Corona) funded by the Italian Ministry for Education, University and Research. The prescribed burning program received financial support by the Parco Nazionale del Cilento e Vallo di Diano.

\section{References}

Alexander ME, Cruz MG (2012) Interdependencies between flame length and fireline intensity in predicting crown fire initiation and crown scorch height. Int J Wildland Fire 21:95-113

Anderson SAJ, Anderson WR (2010) Ignition and fire spread thresholds in gorse (Ulex europaeus). Int J Wildland Fire 19:589-598

Ascoli D, Bovio G (2013) Prescribed burning in Italy: a review of issues, advances and challenges. iForest 6:79-89

Ascoli D, Catalanotti AE, Valese E, Cabiddu S, Delogu G, Driussi M, Esposito A, Leone V, Lovreglio R, Marchi E, Mazzoleni S, Rutigliano FA, Strumia S, Bovio G (2012) Esperienze di fuoco prescritto in Italia: un approccio integrato per la prevenzione degli incendi boschivi. Forest@9:20-38

Baeza MJ, Vallejo VR (2008) Vegetation recovery after fuel management in Mediterranean shrublands. Appl Veg Sci 11:151-158

Bova AS, Dickinson MB (2005) Linking surface-fire behavior, stem heating, and tissue necrosis. Can J For Res 35:814-822

Cohen M, Rigolot E, Etienne M (2002) Modelling fuel distribution with cellular automata for fuel-break assessment. Forest fire research and wildland fire safety. In: Viegas DX (ed) Proceedings of IV International Conference on Forest Fire Research 2002, Coimbra, Portugal. Millpress Science Publishers, Rotterdam, Netherlands

Corona P, Pasta S, Giardina G, La Mantia T (2012) Assessing the biomass of shrubs typical of Mediterranean pre-forest communities. Plant Biosyst 146:252-257

Davies GM, Legg CJ, Smith AA, MacDonald AJ (2009) Rate of spread of fires in Calluna vulgaris-dominated moorlands. J Appl Ecol 46: 1054-1063

De Luis M, Baeza MJ, Raventós J, Gonzáles-Hidalgo JC (2004) Fuel characteristics and fire behaviour in mature Mediterranenan gorse shrublands. Int J Wildland Fire 13:79-87

Dufour-Kowalski S, Courbaud B, Dreyfus P, Meredieu C, de Coligny F (2012) Capsis: an open software framework and community for forest growth modeling. Ann For Sci 69:221-233

Dupuy JL, Alexandrian D (2010) Fire modelling and simulation tools. In: Silva JS, Rego F, Fernandes P, Rigolot E (eds) Towards integrated fire management: outcomes of the European project fire paradox pp 61-69. European Forest Institute, Joensuu, Finland

Fernandes PM, Botelho H, Loureiro C (2002) Manual de Formação para a tecnica de fogo controlado. UTAD, Vila Real, Portugal

Fernandes PM, Cruz MG (2012) Plant flammability experiments offer limited insight into vegetation-fire dynamics interactions. New Phytol 194:606-609

Fernandes PM, Davies GM, Ascoli D, Fernández C, Moreira F, Rigolot E, Stoof CR, Vega JA, Molina D (2013) Prescribed burning in southern Europe: developing fire management in a dynamic landscape. Front Ecol Environ 11:4-14

Fontúrbel MT, Barreiro A, Vega JA, Martín A, Jiménez E, Carballas T, Fernández C, Díaz-Raviña M (2012) Effects of an experimental fire 
and post-fire stabilization treatments on soil microbial communities. Geoderma 191:51-60

Hanley ME (2009) Thermal shock and germination in North-West European Genisteae: implications for heathland management and invasive weed control using fire. App Veg Sci 12:385-390

Iverson LR, Yaussy DA, Rebbeck J, Hutchinson TD, Long RP, Prasad A (2004) A comparison of thermocouples and temperature paints to monitor spatial and temporal characteristics of landscape-scale prescribed fires. Int J Wildland Fire 13:1-12

Krivtsov V, Vigy O, Legg C, Curt T, Rigolot E, Lecomte I, Jappiot M, Lampin-Maillet C, Fernandes P, Pezzatti GB (2009) Fuel modelling in terrestrial ecosystems: an overview in the context of the development of an object-orientated database for wild fire analysis. Ecol Model 220:2915-2926

Lecomte I, de Coligny F, Griffon S, Pimont F, Rigaud E, Rigolot E, Vigy O (2008) Fire Paradox Fuel Manager: User's manual [Final Product P61-6 of the Integrated project "Fire Paradox", Project no FP6018505]. European Commission http://wwweufirelaborg/toolbox $2 /$ library/upload/2778pdf

Madrigal J, Marino E, Guijarro M, Hernando C, Diaz C (2012) Evaluation of the flammability of gorse (Ulex europaeus L.) managed by prescribed burning. Ann For Sci 9:387-397

Mazzoleni S, Bellelli M, Esposito A, Ricotta C, Di Pasquale G, Blasi C (2001) Incendi nel paesaggio vegetale: il caso del Cilento, Campania. L'Italia Forestale e Mont 6:417-428

Molina MJ, Llinares JV (2001) Temperature-time curves at the soil surface in maquis summer fires. Int J Wildland Fire 10:45-52

Morandini F, Silvani X, Rossi L, Santoni PA, Simeoni A, Balbi JH, Rossi JL, Marcelli T (2006) Fire spread experiment across Mediterranean shrub: Influence of wind on flame front properties. Fire Saf J 41: 229-235

Moreira F, Viedma D, Arianoutsou M, Curt T, Koutsias N, Mouillot F, Vaz P, Barbati A, Corona P, Rigolot E, Xanthopoulos G, Bilgili E (2011) Landscape-wildfire interactions in Southern Europe: implications for landscape management. J Environ Manag 92:2389-2402

Morsdorf F, Allgöwer B (2007) Review of fuel description methods [Deliverable D34-2 of the Integrated project "Fire Paradox", Project no FP6-018505]. European Commission

Papiò C, Trabaud L (1991) Comparative study of the aerial structure of five shrubs of Mediterranean shrublands. For Sci 37:146-159

Pausas JG, Alessio G, Moreira B, Corcobado G (2012) Fires enhance flammability in Ulex parviflorus. New Phytol 193:18-23

Pellizzaro G, Cesaraccio C, Duce P, Ventura A, Zara P (2007) Relationships between seasonal patterns of live fuel moisture and meteorological drought indices for Mediterranean shrubland species. Int J Wildland Fire 16:232-241
Pons P, Lambert B, Rigolot E, Prodon R (2003) The effects of grassland management using fire on habitat occupancy and conservation of birds in a mosaic landscape. Biodivers Conserv 12:1843-1860

Puentes A, Basanta M (2002) Architecture of Ulex europaeus: changes in the vertical distribution of organs in relation to plant height and season. J Veg Sci 13:793-802

Rigolot E, de Coligny F, Dreyfus P, Dupuy JL, Lecomte I, Pezzatti B, Vigy O, Pimont F (2010) Fuel Manager: a vegetation assessment and manipulation software for wildfire modeling. In: Viegas DX (ed) Proceedings of the 6th International Conference on forest fire research, Coimbra, Portugal. Millpress Science Publishers, Rotterdam, Netherlands

Santana VM, Baeza MJ, Vallejo VR (2011) Fuel structural traits modulating soil temperatures in different species patches of Mediterranean Basin shrublands. Int J Wildland Fire 20:668-677

Santoni PA, Simeoni A, Rossi JL, Bosseur F, Morandini F, Silvani X, Balbi JH, Cancellieri D, Rossi L (2006) Instrumentation of wildland fire: characterisation of a fire spreading through a Mediterranean shrub. Fire Saf J 41:171-184

Silvani X, Morandini F (2009) Fire spread experiments in the field: temperature and heat fluxes measurements. Fire Saf J 44:279-285

Simões MP, Madeira M, Gazarini L (2012) Biomass and nutrient dynamics in Mediterranean seasonal dimorphic shrubs: strategies to face environmental constraints. Plant Biosyst 146:1-11

Stoof CR, Moore D, Fernandes PM, Stoorvogel JJ, Fernandes RES, Ferreira AJD, Ritsema CJ (2013) Hot fire, cool soil. Geophys Res Lett 40:1534-1539

Strumia S (1995) Sul dinamismo degli arbusteti nei processi di ricolonizzazione nell'Appennino centrale e meridionale analisi floristica ed architetturale di popolamenti a Spartium junceum L. $\mathrm{PhD}$ Thesis, University of Pavia, Italy

Travlos IS, Economou G, Karamanos AJ (2007) Seed germination and seedling emergence of Spartium junceum L. in response to heat and other pre-sowing treatments. J Agron 6:152-156

Ventura JMP, Mendes-Lopes JMC, Rego FMC, Botelho HS (1994) Temperature-time curves in forest fire. In: Viegas DX (ed) Proceedings of II International Conference on Forest Fire Research 2002, Coimbra, Portugal. Millpress Science Publishers, Rotterdam, Netherlands

Wotton BM, Gould JS, McCaw WL, Cheney NP, Taylor SW (2012) Flame temperature and residence time of fires in dry eucalypt forest. Int J Wildland Fire 21:270-281

Zouhar K (2005) Spartium junceum. In: Fire Effects Information System, [Online] US Department of Agriculture, Forest Service, Rocky Mountain Research Station, Fire Sciences Laboratory (Producer). Available:http://wwwfsfedus/database/feis/ 